\title{
Bioterrorism and Dentistry
}

\author{
Amit Chaudhari ${ }^{1}$, Priya Chaudhari ${ }^{2}$
}

\begin{abstract}
In modern world, to spread the confusion and panic among the people terrorist can use biological weapon. In such Bioterrorism attack health professionals plays a key role. This paper reviews the historical aspect, definition, classification of bioterrorism agents and the role of dentistry in such catastrophic event.
\end{abstract}

Key Words: Bioterrorism agents, Medical community

\section{Introduction}

Terrorism is not new, and even though it has been used since the beginning of recorded history it can be relatively hard to define ${ }^{1}$. The term "terrorism" comes from the French word terrorisme, which is based on the Latin verb terrere (to cause to tremble). It dates back to 1795 when it was used to describe the actions of the Jacobin Club in their rule of post-Revolutionary France, the so-called "Reign of Terror". Jacobins are rumored to have coined the term "terrorists" to refer to themselves ${ }^{2}$. Terrorism refers to a strategy of using violence, social threats, or coordinated attacks, in order to generate fear, cause disruption, and ultimately, bring about compliance with specified political, religious, or ideological demands. The European Union includes in its 2002 definition of "terrorism" as the aim of "destabilizing or destroying the fundamental political, constitu-tional, economic or social structures of a country." Terrorism is defined in the U.S. by the Code of Federal Bureau of Investigation as: "The unlawful use of force and violence against persons or property to intimidate or coerce a government, the civilian population, or any segment thereof, in furtherance of political or social objectives." ${ }^{3}$

Terrorists may choose to use biological weapons to achieve their goals because biological agents are relatively cheaper than conventional weapons. Reportedly, many of these agents would be relatively easy to prepare and easy to hide. Their use would also allow bioterrorists to protect themselves and escape before any illness is detected. The most attractive feature of bioweapons, however, maybe the tremendous psychological impact that their use, or threatened use,

Senior Lecturer ${ }^{1}$

Department of Public Health Desntistry, MGM Dental College and Hospital, Kamothe, Navi Mumbai

Senior Lecturer ${ }^{2}$

Department of Prosthodontics, MGM Dental College and Hospital, Kamothe, Navi Mumbai

Address for Correspondence:

Dr. Amit Chaudhari

Department of Public Health Dentistry, MGM Dental College and Hospital, Kamothe, Navi Mumbai

Email ID-phdmgmdch@gmail.com would cause on the population ${ }^{4}$.

The medical community as well as the public should become familiar with epidemiology and control measures for a calm and reasoned response should there be an outbreak ${ }^{5}$. In the event of a bioterrorist attack, most important aspect is the need of trained health professional and in such conditions dentists can render help for increase surge capacities. Dentists may be called upon to fulfill several functions: education, risk communication, diagnosis, surveil-lance and notification, treatment, distribution of medications, decontamination, sample collection and forensic dentistry $^{6}$. Consequently aim of this paper to review ${ }^{1}$. history regarding bioterrorism ${ }^{2}$. classifica-tion of agents $^{3}$. role of dentistry in preparedness.

\section{Historical aspect}

Biological terrorism dates as far back as Ancient Rome, when faeces were thrown into faces of enemies ${ }^{7}$. This early version of biological terrorism continued till the $14^{\text {th }}$ century where the bubonic plague was used to infiltrate enemy cities, both by instilling the fear of infection in residences, so that they would evacuate, and also to destroy defending forces that would not yield to the attack. Over time, biological warfare became more complex. Countries began to develop weapons which were much more effective, and much less likely to cause infection to the wrong party. One significant enhancement in biological weapon development was the first use of anthrax. Anthrax effectiveness was initially limited to victims of large dosages ${ }^{7}$. The development of biological weapons became much more focused in the $20^{\text {th }}$ century. During World War I, Germany was thought to have employed the agents of cholera and plague against humans and anthrax and glanders against livestock ${ }^{8}$. In the period between World Wars I and II, a number of countries, including the USSR, Japan, and the United Kingdom, stepped up their biological warfare research programs. The Japanese effort was notable, with a number of military units engaged in offensive biological weapons research until the end of World War II. During the era of Cold War, the Soviet Union as well as Iraq independently developed their successful biological weapon programs ${ }^{9}$. However, in 1972, Washington and Moscow had agreed by treaty to give up biological 
weapons, but most countries were actively involved in development of such bioweapon facilities ${ }^{9}$.

Bioterrorist events have occurred in recent history both in the United States and abroad. In 1984, the salad bars at two restaurants in the Dalles, Oregon, were contaminated with Salmonella by followers of Bhagwan Shree Rajneesh to prevent citizens from voting in an upcoming election ${ }^{9}$.

One of the most frightening terrorist attacks involved release of the nerve gas sarin in the Tokyo subway system in 1995. Aum Shinrikyo, the cult responsible for killing 12 people and injuring approximately 3,800 in the sarin attack, also attempted to develop botulinum toxin, anthrax, cholera, and $\mathrm{Q}$ fever for bioterrorist us ${ }^{10}$. In 2001, United States experienced bioterrorism attack in the form anthrax spores which were disseminated through postal system ${ }^{9}$.

\section{What is bioterrorism?}

According to Center of Disease Control and Prevention - A bioterrorism attack is the deliberate release of viruses, bacteria, or other germs (agents) used to cause illness or death in people, animals, or plants. These agents are typically found in nature, but it is possible that they could be changed to increase their ability to cause disease, make them resistant to current medicines, or to increase their ability to be spread into the environment. Biological agents can be spread through the air, through water, or in food. Terrorists may use biological agents because they can be extremely difficult to detect and do not cause illness for several hours to several days. Some bioterrorism agents, like the smallpox virus, can be spread from person to person and some, like anthrax, cannot ${ }^{5}$.

\section{Bioterrorism Agent Categories 5}

Bioterrorism agents can be separated into three categories, depending on how easily they can be spread and the severity of illness or death they cause. Category A agents are considered the highest risk and Category $\mathrm{C}$ agents are those that are considered emerging threats for disease.

\section{Category $A$}

These high-priority agents include organisms or toxins that pose the highest risk to the public and national security because:

- They can be easily spread or transmitted from person to person

- They result in high death rates and have the potential for major public health impact

- They might cause public panic and social disruption

- They require special action for public health preparedness.

\section{Category $B$}

These agents are the second highest priority because:

- They are moderately easy to spread
- They result in moderate illness rates and low death rates

- They require specific enhancements of CDC's laboratory capacity and enhanced disease monitoring.

Category $C$

These third highest priority agents include emerging pathogens that could be engineered for mass spread in the future because:

- They are easily available

- They are easily produced and spread

- They have potential for high morbidity and mortality rates and major health impact.

Bioterrorism agents name is given in Table 1.

\section{Dentistry's role in a response}

Bioterrorism attack is a silent attack. Bioterrorism

Table 1: Classification of Bioterrorism Agents

\begin{tabular}{|c|c|c|}
\hline Category A & Category B & Category $\mathrm{C}$ \\
\hline $\begin{array}{l}\text { Anthrax } \\
\text { (Bacillus } \\
\text { anthracis) }\end{array}$ & $\begin{array}{l}\text { Brucellosis } \\
\text { (Brucella } \\
\text { species) }\end{array}$ & $\begin{array}{l}\text { Emerging } \\
\text { infectious } \\
\text { diseases } \\
\text { such as }\end{array}$ \\
\hline $\begin{array}{l}\text { Botulism } \\
\text { (Clostridium } \\
\text { botulinum toxin) }\end{array}$ & $\begin{array}{l}\text { Epsilon toxin } \\
\text { of Clostridium } \\
\text { perfringens }\end{array}$ & Nipah virus \\
\hline $\begin{array}{l}\text { Plague } \\
\text { (Yersinia } \\
\text { pestis) }\end{array}$ & $\begin{array}{l}\text { Food safety threats } \\
\text { (e.g., Salmonella } \\
\text { species, Escherichia coli } \\
\text { O157:H7, Shigella) }\end{array}$ & Hantavirus \\
\hline $\begin{array}{l}\text { Smallpox } \\
\text { (variola major) }\end{array}$ & $\begin{array}{l}\text { Glanders } \\
\text { (Burkholderia mallei) }\end{array}$ & \\
\hline $\begin{array}{l}\text { Tularemia } \\
\text { (Francisella } \\
\text { tularensis) }\end{array}$ & $\begin{array}{l}\text { Melioidosis } \\
\text { (Burkholderia } \\
\text { pseudomallei) }\end{array}$ & \\
\hline $\begin{array}{l}\text { Viral hemorrhagic } \\
\text { fevers (filoviruses } \\
\text { [e.g., Ebola, } \\
\text { Marburg] }\end{array}$ & $\begin{array}{l}\text { Psittacosis } \\
\text { (Chlamydia } \\
\text { psittaci) }\end{array}$ & \\
\hline \multirow{6}{*}{$\begin{array}{l}\text { Arenaviruses } \\
\text { [e.g., Lassa, } \\
\text { Machupo]) }\end{array}$} & $\begin{array}{l}\text { Q fever } \\
\text { (Coxiella burnetii) }\end{array}$ & \\
\hline & $\begin{array}{l}\text { Ricin toxin from Ricinus } \\
\text { communis (castor beans) }\end{array}$ & \\
\hline & $\begin{array}{l}\text { Staphylococcal } \\
\text { enterotoxin B }\end{array}$ & \\
\hline & $\begin{array}{l}\text { Typhus fever (Rickettsia } \\
\text { prowazekii) }\end{array}$ & \\
\hline & $\begin{array}{l}\text { Viral encephalitis } \\
\text { (alphaviruses } \\
\text { [e.g., Venezuelan } \\
\text { equine encephalitis, } \\
\text { eastern equine } \\
\text { encephalitis, } \\
\text { western equine } \\
\text { encephalitis]) }\end{array}$ & \\
\hline & $\begin{array}{l}\text { Water safety threats } \\
\text { (e.g., Vibrio cholerae, } \\
\text { Cryptosporidium parvum) }\end{array}$ & \\
\hline
\end{tabular}


and emerging infectious diseases are a public health issue first, then a criminal investigation. The government and the local health care community must be prepared to respond if they are to effectively limit transmission of the disease and its associated morbidity and mortality, as well as to prevent confusion and panic.

Dentistry can contribute valuable assets, both in personl and in facilities, to the preparation for and in the immediate response to a bioterrorist attack and its aftermath. These assets can make a significant difference in the outcome. In a major bioterrorist attack, the local needs could be massive and immediate. The traditional medical resources-both personnel and facilities- of a community under attack will be overwhelmed, especially in the first few days after the determination that the community has been deliberately subjected to an infectious agent. It will fall to nonphysicians to provide many services ordinarily supplied by physicians (such as performing triage, dispensing medications and providing general medical support). As hospitals become filled, alternate sites for the provision of health care may be required, and dental offices could fill that need ${ }^{11}$.

Guey $\mathrm{AH}^{11}$ reviewed the areas in which dentists can render the help to increase surge capacity in bioterrorism attacks.

Surveillance and notification - Dental offices are distributed across the community, dentists can serve as an excellent surveillance resource. They can detect characteristic intraoral or cutaneous lesions if they are present and report them to public health authorities. They also may be able to detect unusual patterns of employee absences or patients' canceling or missing appointments that are not explainable by recognizable local circumstances. These occurrences may well be a harbinger of serious events about to happen.

Diagnosis and monitoring - Besides assisting in the early identification of the disease or diseases introduced in a bioterrorist attack, dentists can provide individual patient diagnosis by observing the physical and behavioral signs people manifest when the nature of the attack has been determined. Salivary and/or nasal swabs may yield important diagnostic or treatment information and can be collected by dentists for laboratory testing to determine diagnoses when necessary or to monitor treatment progress.

Referral - Dentists can refer suspicious cases to the appropriate specialists for confirmation, treatment or both.

Immunizations - In the event that rapid inoculation or vaccination of the public is required to prevent the spread of infection by a biological agent, dentists may be recruited to assist in a mass inoculation program.

Medications - If the mass population requires treatment, preventive medication or both, pharmacies' capabilities may become overpowered quickly. Dentists could be called on to prescribe and dispense chemotherapeutic or chemoprophylactic medications for the public. When drugs are stockpiled in bulk, dental personnel could help repackage them for individual use before dispensing them.

Triage - Whenever there is a greater number of casualties than the medical care system can accommodate relatively quickly, or whenever medical care resources are overwhelmed, some system for establishing priorities for treatment must be established. Appropriately trained dentists can fulfill this function, thus freeing up medical professionals to provide definitive care for the greatest number of patients.

Medical care augmentation - Because of their training and experience, many dentists may be able to augment and assist medical and surgical personnel in providing definitive treatment for victims of bioterrorist attacks.

Decontamination and infection control - Dentists and dental auxiliaries are well-versed in infection control procedures and can apply their knowledge in reducing the spread of infections- between patients and between patients and caregivers-in mass disasters.

\section{Conclusion}

Dentistry has an important role to play in the response to a significant bioterrorism attack. With adequate preparation, dentistry's valuable assets in terms of personnel and facilities can help in determining that a bioterrorist attack has occurred and in responding to that attack. The profession should develop a disaster response plan that can be integrated into each community's disaster response plan.

\section{References}

1. http://www.terrorism-research.com (accessed on 30.08.11)

2. Golder B, Williams G. What is 'terrorism'? Problems of legal definition. UNSW Law Journal 2004; 27(2): 273-295

3. http://www.legalserviceindia.com/articles/anti_pota.htm (accessed on 30.08.11)

4. http://www.bacteriamuseum.org/cms/PathogenicBacteria/pathogenic-bacteria.html (accessed on 30.08.11)

5. http://www.bt.cdc.gov/agent/agentlist-category.asp

6. http://www.azdhs.gov/phs/edc/edrp/bioterrorism.htm (accessed on 3.09.11)

7. Block, Steven M. The growing threat of biological weapons. American Scientist 2001; 89(1): 28,

8. Christopher, G. W., T. J. Cieslak, J. A. Pavlin, and E. M. Eitzen, Jr. Biological warfare: a historical perspective. JAMA 1997; 278:412-417.

9. Klietmann WF. Ruoff KL. Bioterrorism: Implications for the clinical microbiologist. Clinical Microbiology Reviews $2001 ; 14(2): 364-381$

10. Olson KB. Shinrikyo A. Once and future threat? Emerg. Infect. Dis. 5:513-516

11. Guay AH. Dentistry's response to bioterrorism: A report of a consensus workshop. J Am Dent Assoc September 2002; 133: $1181-118$ 